Uluslararası Sosyal Bilgilerde Yeni Yaklaşımlar Dergisi,2020, 4(2), 335-356

International Journal of New Approaches in Social Studies, 2020, 4(2), 335-356

\title{
4. Sınıf Sosyal Bilgiler Kitabındaki "Milli Mücadele" Konusunun Kronoloji Bilgi ve Becerilerini Kazandırması Açısından Öğretmen ve Öğrenci Görüşleri ile İncelenmesi
}

\author{
Ahmet ŞİMŞEK ${ }^{1}$ \& $\&$ Sevcan KOLBASAR ${ }^{2 *}$ \\ Gönderilme Tarihi: 17 Aralık 2020 \\ Kabul Tarihi: 30 Aralık 2020 \\ DOI: $10.38015 /$ sbyy. 842634
}

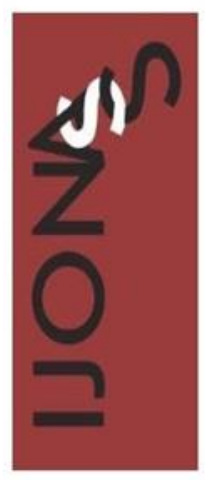

\begin{abstract}
$\ddot{O} z:$
Bu araştırma 2018-2019 yılında uygulamaya geçilen Sosyal Bilgiler dersi programına yönelik hazırlanmış 4. Sınıf Sosyal Bilgiler ders kitabının, "Milli Mücadele” dönemini işlerken kronoloji bilgi ve becerisini ele alış biçimini incelemek amacıyla yapılmıştır. Kitapta Milli Mücadele konusu biyografi temelli bir ögrretimle sunulmuștur. Araştırmada ögrenci ve ögretmen görüs ve bilgilerine başvurulmuştur. Öğrencilerle yapılandırılmış görüşme; öğretmenlerle ise yarı yapılandırılmış görüşme gerçekleştirilmiştir. Yapılan görüşmelerden ortaya çıkan sonuca göre ögrencilerin, "Milli Mücadele" dönemindeki olaylarl kronolojik olarak siralayamadiğg; bu sebeple olaylar arasında sebep-sonuç ilişkisi kuramadiğ l saptanmıştır. Bu durumun çocuklarda "Milli Mücadele" dönemi ile ilgili anlaml olmayan bilgiler yumă̆ şeklinde bir ögrenmeye sebep olduğu söylenebilir. Öğretmenlerle yapılan görüşmelerden çıkan sonuca göre ise Sosyal Bilgiler ders kitabının çocukların seviyesinin üstünde olduğu ve kronoloji bilgi ve becerisini kazanmalarına firsat vermediği sonucuna varılmıştır. Bu çalışma, sonuçları itibari ile Sosyal Bilgiler alanında ders kitabı hazırlanırken kronoloji bilgi ve becerisinin kazandırlmasında dikkat edilmesi gereken hususları göstermektedir.
\end{abstract}

Anahtar Kelimeler: Kronoloji bilgisi, kronoloji becerisi, ders kitabl, Sosyal Bilgiler, Milli Mücadele.

\begin{abstract}
:
This research was carried out in order to examine how "National Struggle" subject of the 4th grade social studies textbook, which prepared for the social studies course program that was put into practice in 2017-2018, provides chronological knowledge and skills. In the book, the subject of National Struggle is presented with a biography-based education. Opinions of students and teachers were consulted in the research. Structured interviews with students and semi-structured interviews with teachers were held. According to the result of the interviews, the students could not list the events of "National Struggle " in chronological order; therefore, it was determined that they could not establish a cause-effect relationship between events. We can say that this situation caused a learning in the form of a cluster of insignificant information about the period of "National Struggle" in children. According to the results obtained from the interviews with teachers, it was concluded that the social studies textbook is above the understanding level of children and does not give them the opportunity to gain chronologcal knowledge and skills. This study shows the points that should be taken into
\end{abstract}

\footnotetext{
${ }^{1}$ İstanbul Üniversitesi, Türkiye. Orcid ID: 0000-0003-3591-8180

${ }^{2}$ İstanbul Üniversitesi, Türkiye. Orcid ID: 0000-0003-3650-8263

*Sorumlu Yazar (Corresponding Author): kolbasarsevcan@gmail.com
} 
consideration in the acquisition of chronological knowledge and skills while preparing a textbook in the field of social studies.

Keywords: chronology knowledge, chronology skills, Social Studies, National Struggle

\section{GíRiş}

Sosyal bir varlık olan insan, bir toplum içinde yaşayan ve yaşadığ 1 topluma göre zihnen biçimlenen, gelişen olaylardan etkilenen, kısacası değişime kayıtsız kalamayan bir yapıdadır. İnsanın bu değişim/gelişim serüvenini farklı disiplinler açısından gözlemlemek mümkün ve anlamlıdır. Bu bağlamda sosyal bilimler, insan ve toplumu, geçmiş ve günümüz ilişkisinde inceler. Bundan ilham alarak ilkokullar için düzenlenen Sosyal Bilgiler ise insanın değişim ve sürekliliğine ilişkin sosyal bilimlerin elde ettiği verilerden yararlanılarak tasarlanmıştır.

Pek çok farklı tanımı olmakla birlikte Sosyal Bilgiler, bireylerde vatandaşlık becerilerini geliştirmek amacıyla sürekli etkileşim halindeki dünyada, "kültürel farklılıkları olan demokratik bir toplumda, genç insanlara bilgiye dayalı ve mantıklı karar alabilme yeteneklerini geliştirmede yardımcı olmaya' (Öztürk 2009, s. 4) çalışır. Bu bağlamda, Türkiye'de ilkokul 4. ve ortaokul 5-6-7. sinıflarda okutulan Sosyal Bilgiler derslerinde, bireylere sadece genel kültür bilgilerinin aktarılması değil, aynı zamanda birçok çağdaş becerinin de kazandırılması amaçlanır.

Türkiye'de Sosyal Bilgiler derslerinde beceri ve değerlerin öğretiminin, 2005 eğitim reformu sonrasında daha çok önemsendiği söylenebilir. Bu bağlamda Sosyal Bilgiler öğretim programlarında da beceri ve değer kazanımı gitgide ön plana çıkmıştır. Sosyal Bilgiler öğretim programı genel amaçlarında, her bir öğrenme alanı (ünite/tema) içinde yer bulan kazanımlarda buna dikkat çekilmiştir. Örneğin, 2020'de uygulamada olan 2018 programına göre Sosyal Bilgiler dersinde 27 farklı becerinin kazandırılması amaçlanmıştır. Bunlardan, mekânı algılama becerisi, zaman ve kronolojiyi algılama becerisi, değişim ve sürekliliği algılama becerisi, sosyal katılım becerisi, empati becerisi Sosyal Bilgiler dersi alanına özgü beceriler iken, diğerleri temel beceriler olarak yer almıştır. Bunlardan ikisi, zaman ve kronoloji becerisi ile değişim ve süreklilik becerisi birbiriyle yakından ilişkili ve tarih eğitimine pedagojik bir giriş yapabilmek adına da önemli bir konumdadır.

\section{Tarihsel Zaman ve Kronoloji İlişkisi}

Zaman kavramını belli bir kalıba ve tanıma sığdırmak, belli başlı kelimelerle net ifade etmek kolay değildir. Bu sebepten, saat ve takvim gibi geleneksel zaman ölçen araçlar dişındaki zaman tanımlamaları, kişiden kişiye farklı anlamlar taşıyabilmektedir. Örneğin bir olayın meydana geliş süreci, bir kişi için oldukça "uzun" bir süreyi ifade ederken, başka biri için oldukça "kısa" olabilmektedir. Şüphesiz ki bu durum, kişinin o anki psikolojik ve fizyolojik haliyle yakından ilgili olduğu kadar, aldığı eğitim, yaşadığı coğrafya (yerleşim yeri), dahil olduğu kültür çevresine göre de farklılık arz edebilmektedir.

İlgili literatür incelendiğinde zamanın geçmiş-şimdi-gelecek halleri dışında fiziksel, tarihsel, sosyal ve psikolojik açıdan konu edildiği görülür. Bunlardan tarihi konu alanı tarihsel zaman olarak tanımlanmıştır. Tarihsel zaman kavramı, adından da anlaşılacağı gibi toplumun ya da dünyanın geçmişinde derin izler bırakan olay ve olguların ele alındığı süreçtir (Şimşek, 2006). Tarihsel zaman kavramı da incelendiğinde bunun öğretime yansıyan üç ana ayağının oluştuğu 
görülür. Bunlar, kronoloji bilgisi, kronoloji becerisi, değişim ve süreklilik algısıdır (Safran ve Şimşek, 2014).

Tarihsel zaman kavramı kapsamında yer alan kronoloji bilgisi; zamanı olayların oluş sırasına göre sunar. Kronoloji, geçmişte yaşanmış olayları, yaşandığı tarihten günümüze doğru zamansal bir dizgiye göre sıralama olarak anlaşılır. Bu yanlış değildir; ancak kronoloji sadece sıralama yapmayı içermez, aynı zamanda olayların sebep-sonuç ilişkisini de ortaya çıkaracak bir ilişkiye de dikkat çeker. Kronoloji bilgisini; çă̆, dönem, milat, yüzyıl, asır, tarih öncesi, milattan önce (MÖ) ve milattan sonra (MS) gibi tarihsel zaman terimleri ve siralama bilgisi oluşturur. Bunlar tarihsel zamanın süreç olarak tanımlanmasında bireylerin başvurdukları anahtarlardir.

Kronoloji becerisi ise, meydana gelen olayları öncelik-sonralık durumuna göre yerleştirebilme ve/veya birden fazla olayı tarihlerine göre konumlandirıp zamansal anlamda mesafelendirebilme becerisidir. Buna ek olarak kronoloji becerisi sayesinde bireyler, hangi olayların birlikte meydana geldiğini, hangisinin önce hangisinin sonra oluştuğunu belirleyebilmektedir (Safran \& Şimşek, 2014). Bu da tarihin hem yazımı hem de öğretimi için vazgeçilmez görünmektedir. Kronoloji becerisi kapsamında, konumlandırma, siralama, yerleştirme, tarihlendirme, mesafelendirme ve eş zamanlılık alt becerileri yer alır (Safran ve Şimşek, 2006).

Tarihsel zamanın diğer bir ana ögesi ise değişim ve süreklilik algısıdır. Bireylerin öncelikle belirli somut gelişmeler üzerinden zamanla gerçekleşen değişimi ve var olan sürekliliği fark etmelerini sağlamayı amaçlar (Safran \& Şimşek, 2014). Bu farkındalık, aynı zamanda bireylerin, toplumsal yapılardaki değişim ve farklılaşma üzerinden sosyal ve kültürel biçimde var olarak süregelen bazı nitelikleri dikkate almalarını sağlar. $\mathrm{Bu}$ yeterlilik sayesinde, karşılaşılan olgu ve kavramların çok daha derinlikli anlaşılması ve açıklanabilmesi mümkün olur.

Sosyal Bilgiler, zamanın farklı boyutlarını toplumsal olgu ve olaylar üzerinden sunarken, bu boyutları somut bir şekilde öğrenciye kazandırmayı da amaçlamaktadır. Öğrenciler, tarihte meydana gelen olaylardan yola çıkarak, zaman, kronoloji ve tarih arasında anlamlı bağlar kurabilir. Zaman ve kronoloji becerisiyle kazandırılması amaçlanan alt beceriler şu şekille ifade edilmiştir (Şimşek, 2016): 


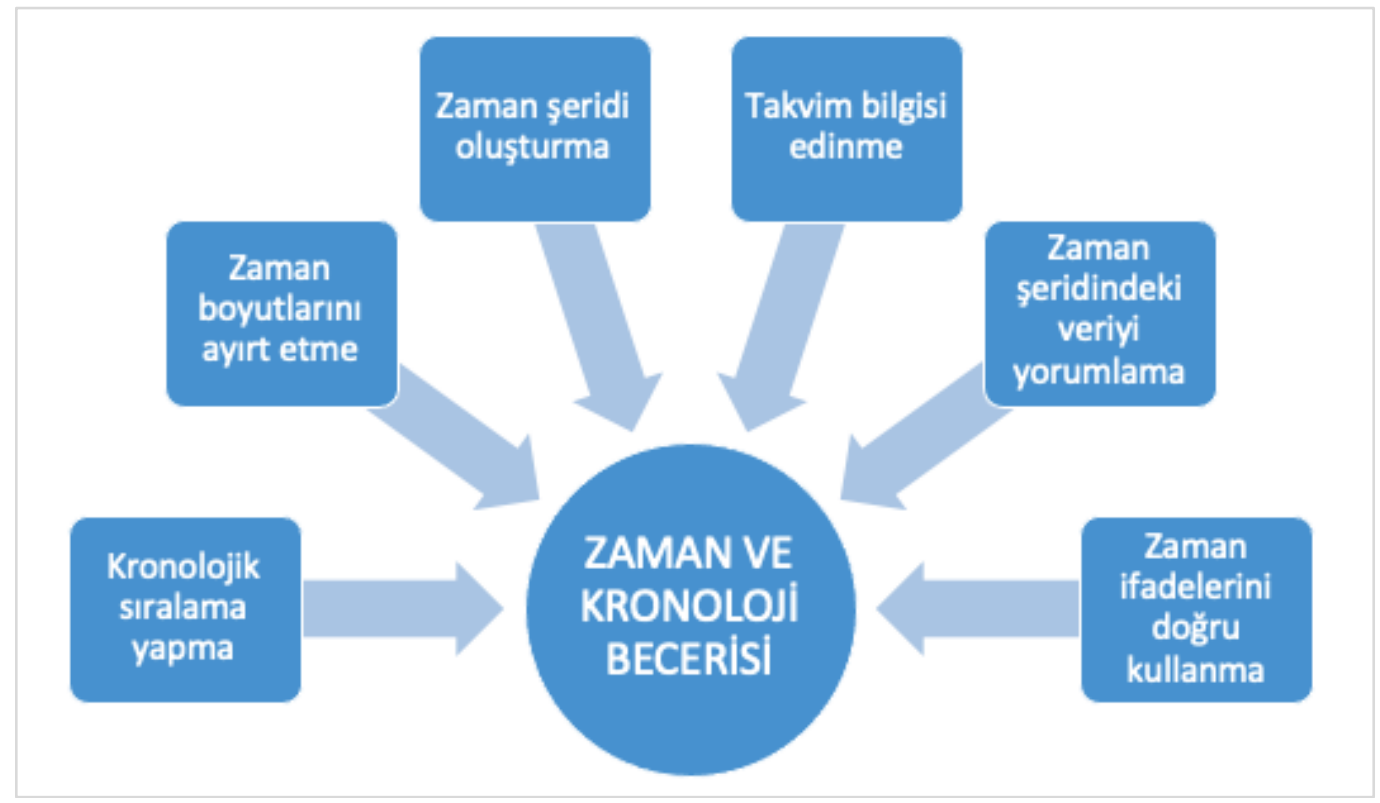

Şekil 1. Zaman ve Kronolojiyi Algılama Becerisine Ait Alt Beceriler

Zamanı algılamak için gerekli olan kavramlar genel olarak soyut oldukları için gelişim çağındaki öğrencilere mutlaka somut örnekler üzerinden sunmak gerekir. Piaget'in araştırmalarından sonra yapılan birçok araştırma çocukların yaşa bağlı zihinsel gelişimlerinin zaman gibi soyut kavramları anlamalarını zorlaştırdığını ortaya koymuştur (Jahoda, 1963; Hallam, 1967). Buna karşın özellikle son 30 yıldır konuya ilişkin yapılan araştırmalarda, yaşa bağlı gelişimsel özellikleri geliştirici bazı etkinlikler yoluyla tarihsel zaman kavramının çok daha erken yaşlardan itibaren kazandırılabileceğini göstermiştir (Blyth, 1996; Hoodles, 1998; Barton, Levstik, 1996, Levstik \& Barton 1997; Hodkinson, 2004, Şimşek, 2007, Hoodless, 2008, De Groot-Reuvekamp, 2017, Sole, 2019). Örneğin bu konuda 2017 yılında Hollanda'da, yaş aralığı 6-12 şeklinde değişen 1457 öğrenci ile yapılan bir çalışmada; tarihsel zamanı öğrenmede ileri yaş grubundaki öğrencilerin daha başarılı olduğu gözlenmesine karşın geliştirilen üç aşamalı bir modelin ilk aşamasının 6-9 yaş aralığında kazandırılabildiği bulgulanmıştır (De Groot-Reuvekamp, Van Boxtel, Oort, 2017). Başka bir çalışmada ise öğrenci performanslarının, cinsiyet ve ebeveyn değişkenlerinden etkilendiği sonucuna varılmıştır (Van Boxtel, Ros, \& Harnett, 2014).

Zaman ve kronoloji bilgi ve becerilerini, öğrenciye kazandırabilmek için onların yaşlarını ve gelişim süreçlerini dikkate alan, çocuklar için eğlenceli bulunan etkinlikler kadar, ilgili öğretim programı ve ders kitaplarının da bu çerçevede düzenlenmesi gerekir. Kavramsal gelişim için okuldaki tarih dersleri şüphesiz ki önemlidir. Bununla ilgili kavram haritaları eğitimin ilk yıllarında oluşturulur (Hoodless, 2008). Öğretim süreci boyunca yapılacak pek çok etkinlikle bu beceriye ait soyut bilgiler somut hale getirilerek, öğrencide kalıcı ve işlevsel bilgi-beceri sağlanabilir.

Diğer yandan, zaman ve kronolojiyle ilgili kavramlar ve işlem becerileri, öğrenciye yeterli düzeyde kazandırılmadığında öğrenci tarihsel olan her olguyu, birbirinden kopuk biçimde görmekte, böylelikle amaçlanan tarih bilinci, öğrencideki gelişmemektedir. Tarihin bilinçli bir şekilde öğrenilmesine giden yol, zaman ve kronoloji becerisinden ve zaman ve kronolojisinde yer alan kavramların öğrencilerce kavranmasından geçmektedir. Eğer öğrenci zaman ve 
kronolojiye ait kavramlara yeterli düzeyde sahip değilse meydana gelen pek çok olayı ve kavramı da doğal olarak algılamayacaktır (Demircioğlu, 2005).

Araştırmanın içeriği ile paralel olacak şekilde Türkçe ve yabancı literatür incelendiğinde tarihsel zamanın öğretimi ile ilgili farklı yaklaşım ve yöntemlerin sunulduğu görülür. Bunlar ana hatlarıyla tarih şeritleri, zaman kapsülleri, çevredeki tarihsel yapılar ve yerel tarih, sözlü tarih yoluyla yaptırılacak soyağacı çalışmaları, aile tarihi yazmak, ya da tarihsel hikâye çözümleridir. Örneğin bunlardan 2018 yılında Hollanda'da yapılan ön-test, son-test ölçekli yarı deneysel bir çalışmada ilkokul 2. sınıf ve 5. sınıf düzeyindeki öğrencilerin tarihsel zaman algılarının gelişimi için kullanılan tarih zaman şeritlerinin faydalı olduğu görülmüştür (Ros, Van Boxtel, 2018). Bir diğer araştırmacı Dawson (2004), ise kronolojiyi anlama becerisini geliştirmeye yönelik fikirlerini sunduğu çalışmasında; zihin haritalarının önemine değinmiştir. Geçmişteki olaylar ve insanlar arasında bağlantılar kurmamızı sağlayan zihin haritalarının kronoloji öğretiminde de işe yarayacağını savunmuştur.

Bütün bu araştırmalar göstermiştir ki çocukların yaşa bağlı zihinsel gelişimlerinden etkilenen tarihsel zaman kavramı ve kronoloji becerilerini, çeşitli özel etkinliklerle erken yaşlardan itibaren geliştirmek mümkün olabilmektedir. Bu nedenle Türkiye'de, ilkokuldan başlamak üzere okutulan Sosyal Bilgiler dersinde, tarihsel zaman ve kronoloji becerileriyle ilgili özel düzenlenmiş öğretim etkinliklerine firsat vermek gereklidir. Bu çerçevede ilkokulda Sosyal Bilgiler dersi tarih konularının öğretiminde tarihsel zaman ve kronolojiye ait kavramların kazandırılmasının temel şartı, bu kavramları öğrencinin yaşamlarıyla ilişkili hale getirmek, böylelikle büyük ölçüde bir anlamda onların zihninde somutlaştırmaktır. Öğrenci kendi yaşamıyla ilişkilendirmediği kavramı sadece ezberleyip, kısa bir süre sonra unutabilmektedir.

Bütün bu imkanlara karşın ilgili literatürde bakıldığında Sosyal Bilgiler dersinin öğretiminde tüm konuları etkileyen bazı sorunlara da rastlanmıştır. Örneğin Taş ve Kıroğlu'nun (2017) ilkokul öğretmenleri ile tarama modelinde yaptığı araştırmaya göre, Sosyal Bilgiler Programının içeriğinin yoğun olması nedeniyle ders sürelerinin öğrenme-öğretme süreçleri açısından yeterli olmadığı, ölçme değerlendirme sürecinde bireysel farklılıkların dikkate alınmadığı, programda belirtilen yöntem ve tekniklerin ders süresi açısından uygulanabilir olmadığı sonuçlarına ulaşılmıştır.

Buraya kadar görüldüğü üzere, ilkokul 4. Sinıfa giden öğrenci için tarihsel zaman kavramları ve kronoloji becerilerinin öğretimi uygun bulunmuştur. Bu çerçevede Türkiye'de sosyal bilgiler dersi için hazırlanmış öğretim programı ve buna bağlı yazılmış ders kitabında tarihsel zaman ve kronoloji becerilerinin yer bulduğu, özellikle bunların öğretiminin Milli Mücadele konusuyla ilişkilendirildiği, bu konunun se 2018 sosyal bilgiler öğretim programında biyografi temelli düzenlendiği görülmüştür. Bu noktada biyografi temelli öğretimin imkan ve sınırlılıklarına kısaca bakmak, konuyu anlamak adına yararlı olacaktır.

\section{Sosyal Bilgilerde Biyografi Kullanımı}

Türk Dil Kurumu Sözlüğünde (1998) öz geçmiş ve yaşam öyküsü diye adlandırılan biyografi, yaşayışları ve yaptıklarıyla ün kazanmış önemli kişilerin hayatlarını belgelere dayalı olarak inceleyen edebi türdür. Eğitim bilimleri bağlamında biyografi ise ilgi merkezi olarak tarihteki önemli kişilerden yararlanarak öğretim amacı ile tarihsel konuları inceleme ve düzene koyma yöntemidir (Kaymakçı \& Er, 2013). 
Sosyal bilgiler öğretiminde biyografi kullanımının pek çok yararı bulunmaktadır. Bunlardan bazıları şöyle açıklanabilir: Biyografiler aracılığıyla kişilerin hayatına odaklanılarak arka planda geniş bir tarihsel sunum yapılır. Biyografiler tarihsel bilginin öğretimini sağlar. Öğrencilerin yer, zaman, kişiler, savaş, barış, siyasi, sosyal ve ekonomik durum gibi birbirinden farklı bilgi ve belgeleri öğrenmelerine olanak sunar. Öğrencilerin eleştirel düşünme, empati kurma, karar verme, okuma ve yazma becerileri ile vatanseverlik, geçmişine saygı duyma, milletini sevme gibi değerleri de geliştirir (Kaymakçı \& Er, 2013). Bu çalışmada da öğrencilerle yapılan görüşmelerden hareketle milli bilincin oluşmasında ve olayların oluş sırasının öğrenci zihninde belirginleşmesinde biyografi kullanımının işe yaradığı söylenebilir.

Biyografi temelli öğretimin gerek öğrenci tutumlarını iyileştirme gerek se bazı değerlerin kazandırılmasında olumlu etki yaptığı bazı araştırmalarda bulgulanmıştır. Bunlardan Er ve Şahin (2012), Sosyal Bilgiler dersinde biyografi kullanımına ilişkin öğrenci görüşlerini belirlemeye ilişkin yaptıkları araştırmada, farklı meslek gruplarına ait birçok kişinin biyografisinin derste olmasına yönelik istekli oldukları tespit edilmiştir. Yine başka bir araştırmada, biyografi temelli etkinliklerle ilkokul 4. sınıf öğrencilerinin hoşgörü değerine yönelik tutumlarının olumlu biçimde geliştirildiği Taş ve Minaz (2019) tarafından tespit edilmiştir. Bir diğer araştırmada ise Kaymakçı ve Şahin (2012) ders kitaplarında biyografinin kullanımına ilişkin yaptıkları çalışmada, Sosyal Bilgiler dersi programında ve ders kitaplarında genel anlamda biyografinin kullanıldığını tespit etmişlerdir.

Bütün bu olumlu araştırma bulguları sonucunda MEB da biyografi temelli öğretim yönteminin kullanımını, 2018 Sosyal Bilgiler dersi programı ile de programın uygulayıc1sı olan öğretmenlere tavsiye etmiştir. Özellikle 4. Sınıf Sosyal Bilgiler dersi "Kültür ve Miras" öğrenme alanının, "Milli Mücadele kahramanlarının hayatlarından hareketle işlenmesi" doğrudan ifade edilmiştir (MEB, 20018).

Sosyal Bilgiler dersinin biyografi temelli işlenmesinin pek çok avantajı olmakla beraber, bazı dezavantajlarının olabileceği de söylenebilir. Bunlar şöyle ifade etmek mümkündür: Tarih içeriğine sahip dersler, yalnızca biyografiler üzerinden planlanır ve işlenirse öğrencilerin zihninde birbirinden bağımsız, bazen kopuk kahramanların hayat hikayelerinden oluşan bazı bilgiler kalabilir. $\mathrm{Bu}$ da çocuklarda tarihsel zaman ve kronoloji becerilerinin gelişmesine olumsuz etkide bulunabilir. Ya da bir dönemi bir kahraman üzerinden işlerken, ilgili kahramanın hayatı çocuğun ilgisini çekmeyebilir. Buna karşın bir çözüm olması için sadece çocukların ilgisini çekecek karakterlerden hareket etmeye çalışırken de ders içeriğine katkı sağlayabilecek önemli kişiler, durumlar ve olaylar ihmal edilebilir. Ayrıca bir kişinin hayatı, bazen bütün olayı anlatabilmek için yeterli olmayabilir (Er, 2005).

Bu çalışmanın amacı, 4. Sınıf Sosyal Bilgiler dersinde MEB tarafından okullara gönderilerek okutulması beklenen ders kitabında yer alan, "Milli Mücadele" konusunun kronoloji bilgi ve becerilerinin bu dersi okutan öğretmenlerin görüşleri ve bu dersi alan öğrencilerin bilgi seviyesini ortaya çıkarmaktır. Belirlenen bu amaç doğrultusunda aşağıdaki sorulara cevap aranmıştır:

Sosyal Bilgiler dersinde "Milli Mücadele" döneminin işlenmesi sürecinde öğretmenler, kendi görüşlerine göre;

1. Hangi yöntem, teknik, kaynak ve materyallere başvurmaktadır?

2. Kullandığı ders kitabı öğrenci seviyesine uygun mudur? Neden? 
3. Biyografi temelli öğretimin faydası var mıdır?

4. Mevcut kitap, kronoloji bilgi ve becerilerinin kazandırılması noktasında yeterli midir?

5. Ders kitabı, öğrencinin değişim ve sürekliliği algılaması için yardımcı olmakta mıdır?

6. Ders kitabının Milli Mücadele dönemi konusunun öğretimini nasıl buluyorsunuz? Neden?

Öğrencilerden ise Milli Mücadelenin tanımı, başlangıcı nedir, süreçteki önemli olayları kronolojik olarak söyleme, Milli Mücadele kahramanlarından öğrenciyi en çok etkileyeni, ders kitabındaki Milli Mücadele ile ilgili bölümde anlamadığı sözcükler, Milli mücadele cepheler, Milli mücadeleyi öğrendiği kaynak bağlamında veri toplamış ve bulgularda sunulmuştur.

\section{YÖNTEM}

Kronoloji bilgi ve becerisinin 4. sınıf Sosyal Bilgiler ders kitabında ele alış biçimini incelemek üzere yapılan bu çalışmanın amacı öğretmen ve öğrencilerin konuyla ilgili görüşlerini belirlemektir. Araştırmacı tarafından görüşülen öğretmen ve öğrencilerin dile getirdiği duygu ve düşüncelerin doğrudan sunulup analiz edildiği bu çalışma, betimsel araştırma olarak hazırlanmıştır. Betimsel analizin yapıldığı çalışmalarda amaç, elde edilen bilgileri düzenlemiş ve yorumlamış bir biçimde okuyucuya sunmaktır. Bu tür çalışmalarda elde edilen veriler sistematik ve açık bir biçimde betimlenir; bu betimlemeler açılanır, yorumlanır ve neden-sonuç ilişkisi içinde irdelenerek birtakım sonuçlara ulaşılır (Yıldırım \& Şimşek, 2008).

\section{Çalışma Grubu}

$\mathrm{Bu}$ araştırmanın iki ayrı çalışma gurubu vardır. İlk çalışma grubunu 2018-2019 eğitim öğretim yılında, İstanbul ili Kağıthane ilçesinde bulunan bir devlet ilkokulunda öğrenim görmekte olan 4. sınıftan 30 öğrenci oluşturmuştur. İkinci çalışma gurubunu ise aynı okulda 4. sınıflara eğitim veren 10 sınıf öğretmeni oluşturmuştur. Öğrenci grubu, okulda altı şube olan 4. Sinıfların her sınıfından beşer öğrenci olmak üzere, kendi sınıf öğretmeleri tarafından rastgele belirlenmiştir. Öğretmenlere ait demografik dağılım aşağıdaki tabloda belirtilmiştir.

Tablo 1. Katılımc1 Öğretmenlerin Demografik Özellikleri

\begin{tabular}{llll}
\hline Katılımc1 & Cinsiyet & Eğitim Durumu & Meslekte Kaçınc1 Y1l \\
\hline A1 & Kadın & Lisans & 16.yıl \\
A2 & Kadın & Lisans & $8 . y 1 l$ \\
A3 & Erkek & Lisans & $8 . y 1 l$ \\
A4 & Kadın & Lisans & $3 . y 1 l$ \\
A5 & Erkek & Lisans & $9 . y 1 l$ \\
A6 & Kadın & Lisans & $9 . y 1 l$ \\
A7 & Kadın & Lisans & $26 . y 1 l$ \\
A8 & Kadın & Lisans & $8 . y 1 l$ \\
A9 & Erkek & Lisans & $23 . y 1 l$ \\
A10 & Erkek & Lisans & $8 . y 1 l$ \\
\hline
\end{tabular}

\section{Veri Toplama Araçlart}

$\mathrm{Bu}$ çalışmada nitel araştırma yöntemlerinden görüşme tekniğine başvurularak veriler toplanmıştır. DeMarris (2004) görüşmeyi, "görüşmeci ve katılımcının birlikte yer aldığı, araştırma yapılan alana yönelik hazırlanan sorulara odaklanarak birlikte konuşma süreci” olarak tanımlanmaktadır. Araştırmada veri toplama aracı olarak öğrenciler için yapılandırılmış, öğretmenler içinse yarı yapılandırılmış görüşme formları kullanılmıştır. Uygulanan görüşme 
formundaki sorular, Sosyal Bilgiler alanında uzman bir eğitimciye de kontrol ettirilerek düzenlenmiştir.

Bilindiği üzere yapılandırılmış görüşmede, görüşmeciye tanınan esneklik sınırlıdır. Bu yaklaşım, zamanı sınırlı bazı insanlardan daha yoğun ve çok, bazı insanlardan ise daha az sistematik ve yüzeysel bilgi edinilmesine yol açabilecek görüşmeci yanlılığını veya öznelliğini azaltmak için göz önünde bulundurulmuştur (Yıldırım \& Şimşek, 2008). Öğrencilerle yapılan görüşmelerde, öğrencilerin konudan sapmalarına engel olmak ve objektif bakış açısını güçlendirmek için yapılandırılmış görüşmeden faydalanmak uygun görülmüştür.

Yarı yapılandırılmış görüşmede ise görüşmeci önceden odaklandığı konuya sadık kalarak ayrıntılı bilgi alabilmek için ek sorular sorma imkanını kullanmıştır. Görüşmeci bu görüşme sırasında bazı ayrıntılara girebilmiştir (Yııldırım \& Şimşek 2008). Bu açıklamadan hareketle, öğretmenlerle yarı yapılandırılmış görüşme yapılmıştır.

\section{Verilerin Analizi}

Betimsel analizde elde edilen veriler, araştırmacı tarafindan önceden belirlenen temalar çerçevesinde ele alınarak incelenir (Yıldırım \& Şimşek, 2018). Bu çalışmada, yapılandırılmış ve yarı yapılandırılmış görüşme tekniği ile elde edilen veriler, araştırmanın amacını oluşturan sorulara cevap vermesi bakımından analiz edilmiştir. Araştırmacı tarafindan oluşturulan çalışmanın alt soruları birer "tema" olarak belirlenmiş; öğretmenlerden ve öğrencilerden görüşme yoluyla elde edilen veriler tek tek analiz edilmiştir.

\section{BULGULAR VE YORUM}

Araştırmada elde edilen verilerin analizi “Öğretmenlerin Görüşlerine İlişskin Bulgular” ve “Öğrencilerin Görüşlerine İlişkin Bulgular” olmak üzere iki başlık altında sunulmuştur.

\section{Öğretmenlerin Görüşlerine İlişkin Bulgular}

Öğretmenlerle yapılan yarı yapılandırılmış görüşme formu, açık uçlu altı sorudan oluşmaktadır. İlk iki soru öğretmenlerin "Milli Mücadele" konusunu işlerken başvurduğu öğretim yöntemlerini ve kaynaklarını değerlendirmeye yönelik sorulmuştur. Diğer sorular (3. 4. 5. ve 6 . sorular) ise, ders kitabının "Milli Mücadele" dönemini işlediği bölümlerde, öğrencinin bulunduğu gelişimsel sürece uygunluğunu, kronoloji bilgi ve becerisini vermeye yönelik yeterliğini belirlemek üzere sorulmuştur.

Bulgu/Soru 1: "Sosyal Bilgiler dersinde "Milli Mücadele" döneminin işlenmesi sürecinde hangi yöntem teknik ve kaynaklara başvuruyorsunuz?"

Görüşmedeki ilk sorunun amacı 4. Sınıf öğretmenlerinin "milli mücadele" konusunu işleme sürecinde hangi yöntem-teknik ve kaynakları kullandıklarını belirlemektir. Öğretmenlerin sorusuna verdikleri yanıtlar aşağıdaki gibidir:

Tablo 2. Öğretmenlerin Kullandığı Yöntem-Teknik ve Kaynaklara İlişkin Görüşleri

\begin{tabular}{llc}
\hline Yöntem-Teknik & Kişi & Yüzdelik \% \\
\hline Anlatım & 9 & $\% 90$ \\
Soru-cevap & 6 & $\% 60$ \\
Canlandırma & 2 & $\% 20$ \\
\hline
\end{tabular}


Tablo 2'ye göre öğretmenlerin "Milli Mücadele" konusunu işleme sürecinde çoğunlukla anlatım yöntemini kullandığ 1 görülmektedir. Aynı zamanda kullanılan yöntemlerden ikinci sırada soru-cevap yöntemi gelirken; canlandırma yöntemi en az kullanılan yöntem olarak görülmüştür. Canlandırma yöntemini kullanan öğretmenlerden A3 canlandırma yönteminin etkisini söyle dile getirmiştir: "EBA (Eğitim Bilişim Ağı)'dan indirdiğim "Milli Mücadele Yolu" adlı videoyu öğrencilerime izlettim. Ardından gönüllü öğrencilerle bu videonun canlandırmasını drama yöntemi ile yaptık. Bu sayede öğrencilerin öğrenme sürecine aktif olarak katılımını sağladım. Bu durum anlamlı ve kalıcı öğrenmelerine olumlu etki etti.”

Öğretmenlerin sadece üç öğretim yönteminden bahsetmesi belki de konunun öğretimindeki en önemli eksikliğe dikkat çekmektedir. Bu üç yöntem dişında öğretmenlerin başka yöntem ve teknik belirtmemesi, şüphesiz ki üzerinde durulması gereken bir konudur. Çünkü çağdaş öğretim yaklaşımlarında öğrenciyi merkeze alan yöntem ve teknikleri kullanmak, öğrencinin ilgisini daha çok derse odakladığ 1 gibi, konu edilen bilgilerin çok daha kalıcı ve anlamlı olmasına katkı sağlar. Anlatım yönteminde ise öğretmen aktif ve bilgiyi aktaran konumunda iken; öğrenci pasif ve bilgi alıcı konumundadır.

Anlatımı sık kullanmak, öğretmenlerin anlamlı öğretim sürecinde zamandan kazanç sağlamak ve pratik olması açısından tercih edilen bir yöntemdir. Ancak sadece anlatım yönteminin kullanıldığı durumda öğrencinin anlamlı ve kalıcı bilgiye ulaşması zorlaşır. Kullanılan yöntem ve tekniklerin çeşitliliği konunun daha çok öğrenci tarafından doğru anlaşılmasına yardımcı olabilir. Sadece anlatım yönteminin kullanılması öğretimin etkisini azaltır. Bilginin içselleştirmesine firsat vermez, öğrenciyi ezberciliğe teşvik eder (Erciyeş, 2017).

Tablo 3. Öğretmenlerin öğretim sürecinde faydalandığı kaynak ve materyaller

\begin{tabular}{llc}
\hline Öğretim Materyalleri & Kişi & Yüzdelik \\
\hline Kaynak kitaplar & 7 & $\% 70$ \\
Haritalar & 6 & $\% 60$ \\
Videolar & 5 & $\% 50$ \\
Çevrimiçi İnternet siteleri & 3 & $\% 30$ \\
Sosyal Bilgiler Ders Kitabı & 3 & $\% 30$ \\
Biyografi şeklinde hazırlanmış hikâye kitapları & 1 & $\% 10$ \\
\hline
\end{tabular}

Araştırma açısından Tablo 3'ye yansıyan diğer bir durum ise öğretmenlerin öğretim sürecinde faydalandığı kaynak ve materyaller ile ilgili olarak; ilk sırada "kaynak kitaplar" yer almaktadır. Yapılan görüşmelerde öğretmenler; "özet bilgilere ulaşmak için" "kaynak kitaplar" a başvurduklarını ifade etmişlerdir. Öğretmenlerden A4 neden "kaynak kitap" kullanma ihtiyacı hissettiğini şöyle dile getirmişti: "Sosyal Bilgiler ders kitabı seviyenin üstünde ve fazla ayrıntı içermektedir. Örneğin ders kitabında Kurtuluş Savaşı'nda cepheler konusu sekiz sayfa boyunca anlatılmış. Bu sebeple cepheler bölümünü anlatırken ders kitabı dışındaki kaynak kitaplara başvurdum. Kitapta cepheler daha öz ve ana hatları ile anlatılabilirdi.” Öğretmenlerden A7 ise neden "kaynak kitap" kullandığını şöyle açıklamıştır: "Herhangi bir lise sosyal bilgiler ders kitabında ya da 7. 8. Sınıf sosyal bilgiler ders kitabında milli mücadele dönemi ile ilgili görebileceğiniz her konuyu bizim bu yıl okuttuğumuz 4. Sınıf sosyal bilgiler kitabında da görebilirisiniz. Örneğin 4. sınıf seviyesindeki bir öğrenciye Batı cephesinde olan tüm savaşları en ince ayrıntısına kadar vermek doğru değildir. Bu kadar bilgi hem çocuğun seviyesini aşar hem de anlamadığından sıkılmasına sebep olur.” İki öğretmenin cevaplarında ortak nokta; mevcut ders kitaplarındaki "Milli Mücadele" konusunun işlenişinin öğrencilerin seviyesine 
uygun olmadığı, kitapta karmaşık biçimde sunulan konuları bu kaynak kitaplarla kolaylaştırmak olmuştur.

Bulgu/Soru 2: "Milli Mücadele bölümünü işlerken ders kitabından faydalandınız mı? Ders kitabında, Milli mücadele konusu sizce öğrenci seviyesine uygun olarak hazırlanmış mı? Bu konudaki görüşleriniz nelerdir? Örneklendirin.”

Tablo 4. Ders Kitabının Seviyeye Uygun Olup Olmadığına İlişkin Öğretmen Görüşleri

\begin{tabular}{lll}
\hline Soru: 2 & Uygun & Uygun Değil \\
\hline Ders kitabı öğrenci seviyesine uygun mudur? & 2 kişi $(\% 20)$ & 8 kişi $(\% 80)$ \\
\hline
\end{tabular}

Tablo 4'e bakıldığında araştırmaya katılan öğretmenlerin çoğunluğunun mevcut ders kitabının öğrencinin seviyesine uygun olmadığını düşündükleri görülmektedir. Görüşmenin ikinci sorusu ile ilgili olarak A3; "Evet ders kitabından faydalandım fakat milli mücadele sürecinin anlatımında öğrencilerin anlayamayacağı çok sözcük olması (taarruz, heyet, muharebe, karargâh, antlaşma, ateşkes, mütareke, mareşal, güzergâh vb.) ve fazla ayrıntıya yer vermesi sebebiyle seviyeye uygun olduğunu düşünmüyorum. Bazı olay ve kavramlar da soyut olduğundan öğrencilerin anlaması zordu." şeklinde görüşlerini ifade etmiştir. Görüşmeye katılan diğer öğretmenlerin de yedisi genel olarak seviyeye uygun olmadığını ifade etmişler; bir öğretmen seviyeye uygunluğunu A6; "k1smen uygun buluyorum." şeklinde dile getirirken; diğer öğretmen ise A9; "Önceki yıllarda faydalandığımız ders kitapları ile kıyasladığımda bu ders kitabının daha kullanışlı ve seviyeye uygun olduğunu düşünüyorum.” şeklinde görüşünü beyan etmiştir.

Ders kitapları, dersin öğretiminde öğrencilerin hem ders içinde hem de ders dişında kendi kendilerine kolaylıkla öğrenme imkânı bulabilecekleri, içeriği ilgi çekici ve ekonomik biçimde sunması beklenen öğretim materyalleridir. Bu araştırmaya konu olan Sosyal Bilgiler ders kitabı ise öğretmenlerin görüşme sırasında verdikleri cevaplardan anlaşıldığına göre daha az kullanılan öğretim materyali durumuna düşmüştür. Bu durumun sebebi, görüşmedeki diğer soruların analizi ile daha da aydınlığa kavuşmaktadır. Burada da kısaca belirtmek gerekirse tüm öğretmenlerin görüş birliği ile "ders kitabının sınıf seviyesinin üstünde ve fazla ayrıntı içermesi” şeklinde ifade etmesini, ek kaynaklara ihtiyaç duyulmasına sebep olarak göstermişlerdir.

Bulgu/ Soru 3: "Sizce milli mücadele konusunun Sosyal Bilgiler ders kitabında olduğu gibi biyografi temelli işlenmesinin faydası var mıdır?” sorusuna ilişkin öğretmen görüşleri

$\mathrm{Bu}$ noktada hemen belirtmek gerekir ki MEB sosyal bilgiler öğretim programında biyografi temelli öğretime doğrudan bir atıfla dersin ilgili kazanımını şöyle belirlemiştir:

“SB.4.2.4. Millî Mücadele kahramanlarının hayatlarından hareketle Millî Mücadele'nin önemini kavrar. Kazanım biyografi öğretimi bağlamında ele alınır.” 
Tablo 5. Ders Kitabının Milli Mücadele Konusunu Biyografi Temelli Sunmasının Öğrenciye Yararına İlişkin Öğretmen Görüşleri

\begin{tabular}{lll}
\hline Soru: 3. & Uygun & Uygun Değil \\
\hline $\begin{array}{l}\text { Ders kitabının Milli Mücadele konusunu biyografi temelli işlemesinin } \\
\text { ögrenciye yararı var mıdır? }\end{array}$ & 3 kişi (\%30) & 7 kişi (\%70) \\
\hline
\end{tabular}

Görüşme sonuçlarına göre öğretmenlerin büyük çoğunluğu Milli Mücadele döneminin işlenmesinde biyografi temelli olarak konunun ele alınmasının faydalı olmadığını dile getirmişlerdir. Öğretmenlerden A2 biyografi temelli sunumun "milli mücadele ruhu" ile örtüşmediğini şöyle ileri sürmüştür: "Biyografi temelli işlenmesi diğer ayrıntıların göz önünde bulundurulmasını engelliyor. Ne de olsa milli mücadele bir halk mücadelesidir. Kişilere indirgenmemelidir." Başka bir öğretmen A7 ise mevcut yaklaşımın uygun olmadığını kesin bir dille şöyle belirtmiştir: "Hayır faydası yoktur. Amaç olayın bilinmesidir, kim tarafından ne zaman olduğu gibi bilgiler detaydır. Bence önemli olan öğrenciye milli mücadele ile ilgili duyuşsal açıdan bir şeyler kazandırmak olmalıdır." Biyografi temelli işlemenin faydalı olduğunu savunan öğretmenlerden A10 ise özellikle öğrencilerin seviyelerine uygun olmas1 şartı ile durumu şöyle özetlemiştir: "Milli Mücadeleyi işlerken milli mücadele kahramanları üzerinden konunun ele alınması öğrencinin empati yapmasını sağlıyor. O dönemde yaşamış kişilerin hayatlarından hareketle işlenmesi ayrıca öğrencide merak uyandırıyor. Seviyeye uygun olarak hazırlanması şartıyla biyografi temelli işlenmesini faydalı buluyorum." $\mathrm{Bu}$ açılamalardan hareketle Milli Mücadele döneminin mevcut şekliyle biyografi temelli işlenmesinin, öğretmenler tarafından faydalı bulunmadığı görülmüştür. Öğrencilerle yapılan görüşme analizlerinde de aynı konu ele alınacaktır.

Bulgu/ Soru 4: "Sizce ders kitab1 Milli mücadele konusunu sunarken kronoloji bilgi ve becerilerinin kazandırılması noktasında yeterli mi?"

Tablo 6. Ders Kitabının Kronoloji Bilgi-Becerisini Sunmasına İlișkin Öğretmen Görüşleri

\begin{tabular}{lll}
\hline Soru: 4. & Uygun & Uygun Değil \\
\hline $\begin{array}{l}\text { Ders kitabı kronoloji bilgi ve becerisi kazandırması açısından yeterli } \\
\text { midir? }\end{array}$ & 2 kişi (\%20) & 8 kişi (\%80) \\
\hline
\end{tabular}

Öğretmenlere sorulan bu soruda yine çoğunluk 4.sınıf Sosyal Bilgiler ders kitabının Milli Mücadele dönemini sunarken kronoloji bilgi ve becerisini kazandırma noktasında yetersiz olduğunu düşündüğünü belirtmiştir. Öğretmenlerden A5: "Kesinlikle yetersiz. Kitapta milli Mücadele dönemi ile ilgili çok ayrıntı verildiği için öncelik sırası anlaşılmıyor ya da çoğu kez karıştırılıyor" şeklinde ifade etmiştir. Öğretmenlerden A2 ise; "Yardımcı oluyor ama yeterli değil. Milli Mücadele konusu soyut olduğu ve sıralı olaylar içerdiği için kitapta tarih cetvelleri ya da konuya ilişkin olay haritaları yer almalıydı. Bu sayede kronoloji bilgi ve becerisi daha iyi kavranabilirdi” şeklindeki ifadesiyle, ders kitabının bu konudaki eksikliğini dile getirmiş; bununla beraber kendi önerilerini belirtmiştir.

Bulgu/ Soru 5: “Öğrencinin değişim ve sürekliliği algılaması için ders kitabı yardımcı oluyor mu?" 
Tablo 7. Ders Kitabının Değişim ve Süreklilik Becerisini Kazandırmasına İlişkin Öğretmen Görüşleri

\begin{tabular}{lll}
\hline Soru: 5 & Uygun & Uygun Değil \\
\hline $\begin{array}{l}\text { Ders kitabı, öğrencinin değişim ve sürekliliğ̣i algılaması için yardımc1 } \\
\text { oluyor mu? }\end{array}$ & 2 kişi (\%20) & 8 kişi (\%80) \\
\hline
\end{tabular}

Görüşme sırasında öğretmenlere yöneltilen bu soruda öğretmenlerin çoğunluğu ders kitabının değişim ve süreklilik becerisini kazandırmada yetersiz olduğunu düşünmüştür. Öğretmenlerden A1, şu ifadesi ile ders kitabının kronoloji bilgi ve becerisini kazandırmada yetersiz olmasını eleştirmiştir: "Kronoloji becerisi için kavram haritaları ve olayları sırasıyla gösteren şemalar önemlidir. Fakat kitapta böyle bir harita kullanılmamış. Ben öğrencilerime Milli Mücadele'yi kısaca özetleyen bir şema ile anlattım. Olayların oluş sırasını öğrenmede bunun işe yaradığını düşünüyorum."

Öğretmen A8 ise şöyle demiştir: "Ders kitabında milli mücadele dönemi biyografi temelli işlendiği için öğrenci kahramanların hayatı ile ilgili bölümleri okurken asıl olaydan bağımsız olarak düşünüyor ve olay sıralaması karışıyor." Öğretmen A5 ise şöyle ifade ederek değişim ve süreklilik becerisinin kazandırılmasında ders kitabının yeterince etkili olmadığını dile getirmiştir: "Öğrencilerin geçmiş ve günümüz arasındaki gelişim ve değişimleri fark edebilmesi için ders kitabında yeterli örnekler verilmeli. Ancak sadece geçmişte yaşanmış olayların sunulması günümüzle karşılaştırma yapılmasına engel oluyor.” Bir önceki soruda kronoloji bilgi ve becerisinin kazandırılmasında ders kitabını yetersiz gören öğretmenlerle, bu soruda değişim ve süreklilik becerisini kazandırmada ders kitabını yetersiz görenler aynı kişilerdir. $\mathrm{Bu}$ veriden yola çıkarak çalışmanın giriş kısmında da belirtildiği üzere, 2018 ilkokul 4. Sınıf sosyal bilgiler dersi için kazandırılması hedeflenen temel becerilerden olan "kronoloji becerisi" ile "değişim ve sürekliliği algılama becerisi" bakımından ders kitabının yeterli olmadığ söylenebilir.

Bulgu/ Soru 6: "Ders kitabının Milli Mücadele dönemi konusunun öğretimini nasıl buluyorsunuz? Neden?"

$\mathrm{Bu}$ soru ile öğretmenlerden, ders kitabının Milli Mücadele konusunu genel olarak değerlendirmeleri beklenmiştir. Görüşmeye katılan öğretmenlerin tümü ders kitabını bu konuyu işleyiş bakımından sınıf seviyesinin üstünde bulduklarını ifade etmişlerdir. Ayrıca öğretmenlerin geneli bu konu ile ilgili olarak kitapta fazla ayrıntı bilgi verildiğini belirtmişlerdir. Öğretmenlerden A9 şöyle demiştir: “ Ders kitabının özellikle Milli Mücadele konusunda ezbere dayalı olarak hazırlandığını düşünüyorum. Ezberlenen bilgi öğrenilen bilgi değildir. Öğrenci içselleştiremez ve çabuk unutulur. Daha sade ve öz bir anlatımla görsel olarak zenginleştirilebilirdi. Açıkçası ben kitapta ayrıntı olarak gördüğüm birçok konuyu derste işlemedim." Öğretmen A9 bu ifadesi ile ders kitabını hem içerik olarak fazla detaycı bulmuş; hem de konunun işlenişi bakımından ezbere dayalı olmasını eleştirmiştir.

\section{Öğrencilerin Görüşlerine İlişkin Bulgular}

Öğrencilerle gerçekleştirilen yapılandırılmış görüşmeler, her bir sorunun ayrı değerlendirilmesi şeklinde ele alınmıştır. Aşağıdaki tabloda öğrencilerin görüşme sorularına verdiği cevaplar sayısal olarak sunulmuştur. 
Tablo 8. Öğrencilerin görüşme sorularına verdiği cevaplara ilişkin sayısal veriler

\begin{tabular}{|c|c|c|c|}
\hline Sorular & Cevaplar & $\begin{array}{l}\text { Cevap } \\
\text { Sayısı }\end{array}$ & Yüzdelik\% \\
\hline \multirow[t]{2}{*}{ 1. Milli Mücadele sözünden ne anlıyorsun? } & Doğru & 14 & 46,7 \\
\hline & Yanlış/Boş & 16 & 53,3 \\
\hline \multirow[t]{2}{*}{ 2. Milli Mücadelenin başlangıcı olan olay nedir? } & Doğru & 15 & 50,0 \\
\hline & Yanlış/Boş & 15 & 50,0 \\
\hline \multirow{10}{*}{$\begin{array}{l}\text { 3. Milli Mücadele sürecindeki önemli olayları oluş sırasına } \\
\text { göre (Kronolojik olarak) söyler misin? } \\
\text { 4. Milli Mücadele kahramanlarından seni en çok etkileyen } \\
\text { hangisi oldu? Açıklar mısın? }\end{array}$} & Doğru & 13 & 43,3 \\
\hline & Yanlış/ Boş & 17 & 56,7 \\
\hline & Kazım & 9 & 30,0 \\
\hline & Karabekir & & \\
\hline & Şerife Bacı & 11 & 36,7 \\
\hline & M. Kemal & 6 & 20,0 \\
\hline & Atatürk & & \\
\hline & Vecihi & 2 & 6,7 \\
\hline & Sütçü İmam & 1 & 3,3 \\
\hline & Şekerci Ökkeş & 1 & 3,3 \\
\hline \multirow{4}{*}{$\begin{array}{l}\text { 5. Ders kitabındaki Milli Mücadele ile ilgili bölümde } \\
\text { anlamadığın sözcükler oldu mu? } \\
\text { 6. Milli mücadele süresince hangi cephelerde savaşılmıştır? }\end{array}$} & Var & 23 & 76,7 \\
\hline & Yok & 7 & 23,3 \\
\hline & Doğru & 22 & 73,3 \\
\hline & Yanlış/Boş & 8 & 26,7 \\
\hline \multirow{2}{*}{$\begin{array}{l}\text { 7. Milli mücadeleyi öğrenmende sana en çok faydası olan } \\
\text { kaynak nedir? ( Ders kitabı, öğretmen, haritalar vb. gibi } \\
\text { görseller, izlediğin bir video...) }\end{array}$} & Öğretmen & 24 & 80,0 \\
\hline & Kitap & 6 & 20,0 \\
\hline
\end{tabular}

Soru 1: Milli Mücadele sözünden ne anlıyorsun?

Bu soruya verilmesi beklenen cevaplarda bazı anahtar ifadelerin yer alması beklenerek, buna göre sorunun doğru cevaplanıp cevaplanmadığına karar verilmiştir. Bu ifadeler araştırmanın da aynı zamanda katılımcısı olan 4. Sınıf öğretmenlerince belirlenmiştir. Cevapta olması beklenen anahtar ifadeler: "bağımsızlık için milletçe mücadele", "halkın hep birlikte kenetlenmesi", "Atatürk'ün Önderliğgi", "milli birlik", "fedakârlık", "kahramanlık" "özgürlük mücadelesi" ...vb. şeklinde belirlenmiştir. Bu açıklamaların ışığında aşağıdaki tabloda 1. Sorunun cevap dağılımı gösterilmektedir:

Tablo 9. Öğrenci Görüşme Formu 1. Soru Cevap Dağılımı

\begin{tabular}{llll}
\hline Soru & Cevaplar & $\begin{array}{l}\text { Cevap } \\
\text { Sayısı }\end{array}$ & \multirow{2}{*}{ Yüzdelik\% } \\
\hline \multirow{2}{*}{ 1. Milli Mücadele sözünden ne anliyorsun? } & Doğru & 14 & 46,7 \\
& Yanlıs/Boş & 16 & 53,3 \\
\hline
\end{tabular}

$\mathrm{Bu}$ soruyu bilemeyen öğrencilerin cevaplarına baktığımızda, hatanın kendini doğru ifade edememekten kaynaklandığı söylenebilir. Bu sorunun cevabına ilişkin, 4. sınıf öğrencisinin kurması beklenen cümleleri kuramadığı, soruyu kısmen anlamış olsa da doğru ifadelerle cevap veremediği aşağıda verilen cevaplardan anlaşılmaktadır:

- Ö-16: "Savaşan insanları anlıyorum."

- Ö-3: "Atatürk'ü anlıyorum."

- Ö-12: “Atatürk'ü ve arkadaşlarını anlıyorum."

- Ö-7: “Atatürk'ün savaştığını anlıyorum.” 
- Ö-26: "Mondros ateşkesi anlıyorum."

- Ö-24: "Vatanı anliyorum."

Birinci soruya istenen cevabı veremeyen öğrencilerin ifadelerine bakıldığında genel olarak kendini ifade etme becerilerinin eksik olduğu sonucuna ulaşıllyor. Bununla beraber "Milli Mücadele" kavramını sadece Atatürk'e bağladıklarını, "milletçe bir başkaldırı" ya da "milletçe bir bağımsızlık mücadelesi” olarak öğrenemedikleri görülüyor.

Soru 2: Milli Mücadelenin başlangıcı olan olay nedir?

Katılımcı öğrencilerin Milli Mücadele döneminde olayları oluş sırasına göre öğrenip öğrenemediğini değerlendirmek amacıyla sorulan bu sorunun cevap dağılımı tablodaki gibidir:

Tablo 10. Öğrenci Görüşme Formu 2. Soru Cevap Dağılımı

\begin{tabular}{llll}
\hline Soru & Cevaplar & $\begin{array}{l}\text { Cevap } \\
\text { Sayısı }\end{array}$ & \multirow{2}{*}{ Yüzdelik\% } \\
\hline \multirow{2}{*}{ 2. Milli Mücadelenin başlangıcı olan olay nedir? } & Doğru & 15 & 50,0 \\
& Yanlış/Boş & 15 & 50,0 \\
\hline
\end{tabular}

Bu soruyu öğrencilerin yarı yarıya doğru cevapladığı görülmektedir. Soruyu bilen ve bilmeyen öğrenci sayısı eşittir. Burada yeterli bir öğrenmeden bahsetmek zordur.

Bu sorunun cevabı ile ilgili 8 öğrenci "hatırlamıyorum" şeklinde cevap verirken 7 öğrenci ise "milli mücadele"nin başlangıcı ile ilgili "Samsun'a çıkması ile başlar." diyemeyip; başka bir olayı söylemiştir. Verdikleri cevaplar aşağıdaki gibidir:

- Ö-22 veÖ-28“Çanakkale savaşı ile başlar",

- Ö-16 ve Ö-7: "Trablusgarb savaşı ile başlar.",

- Ö-29: "Yunanlıların İzmir'i işgali ile başlar."

- Ö-11 ve Ö-21: "1.Dünya savaşı ile başlar."

Yukarıda soruya verilen yanlış cevaplara baktığımızda öğrencilerin kronolojik olarak Milli Mücadele dönemini öğrenemediği görülmektedir.

Soru 3: Milli Mücadele sürecindeki önemli olayları oluş sırasına göre (kronolojik olarak) söyler misin?

Tablo 11. Öğrenci Görüşme Formu 3. Soru Cevap Dağılımı

\begin{tabular}{llll}
\hline Soru & Cevaplar & $\begin{array}{l}\text { Cevap } \\
\text { Sayısı }\end{array}$ & Yüzdelik\% \\
\hline 3. Milli Mücadele sürecindeki önemli olayları oluş sırasına & Doğru & 13 & 43,3 \\
göre (Kronolojik olarak) söyler misin? & Yanlış/Boş & 17 & 56,7 \\
\hline
\end{tabular}

Görüşme yapılan öğrencilere bu sorunun sorulmasındaki amaç, Milli Mücadele'de gerçekleşen önemli olayların kronolojik olarak öğrenilip öğrenilmediğinin belirlenmesidir. Soruya verilen cevapların dağılımı yukarıdaki tabloda yer almaktadır. Bu sonuca göre sıralama yapamayan öğrenci sayısı fazla çıkmıştır. Bu durum kronoloji becerisinin genel olarak öğrenilmediğini göstermiştir. 
4. sınıf Sosyal Bilgiler ders kitabında "Milli Mücadele" dönemi, kronolojik olarak verilmeyip; açılan (Batı, Doğu ve Güney) cephelerde yaşanan gelişmelerle anlatılmıştır. Ders kitabında genel olarak Milli Mücadele kronolojik bir sırada verilmemesine karşın, yalnızca Atatürk'ün hayatının anlatıldığı bölümde şöyle bir sıralama yapılmıştır:

1. 19 Mayıs 1919 'da Atatürk'ün Samsun'a çıkışı,

2. Havza ve Amasya'da genelgeler yayınlayarak halkı bilgilendirmesi,

3. Sirasiyla Erzurum ve Sivas Kongrelerini yapmas1,

4. 23 Nisan 1920'de TBMM’yi açması,

$\mathrm{Bu}$ sorunun cevabı ile ilgili olarak öğrencilerin yukarıdaki sıralamayı yapmaları beklenmiştir. Bu soruya 6 öğrenci kitapta belirtilen sıralamada dahi olmayan olayları söyleyerek cevap verirken; 4 öğrenci hatırlamıyorum şeklinde cevap vermiş; 4 öğrenci yukarıda belirtilen sıralamayı karıştırmış; 3 öğrenci de olaylardan birini eksik söylemiştir. Yanlış cevapların bazıları aşağıdaki gibidir:

- Ö-11: “1.Dünya Savaşı oldu. Sonra Çanakkale Savaşı'nı kazandık. Mondros Ateşkes’i imzaland1. Atatürk kabul etmedi ve Kurtuluş Savaşı başladı.”

- Ö-29: "1920'de TBMM açıldı ve sonra 1923'de cumhuriyet kuruldu."

- Ö-18: "Atatürk doğdu. Büyüdü. Askeri okula gitti. Harp okuluna gitti. Paşa oldu. Amasya ve Erzurum'a gitti. Mücadele Ankara'da bitti."

Öğrencilerin verdiği yanlış cevaplara baktığımızda bilgi karmaşası yaşadıklarını, öğrendiklerini kronolojik biçimde sıralayamadığı söylenebilir. Bu durum 4. Sınıf Sosyal Bilgiler ders kitabının kronoloji bilgi ve becerisini kazandırmada yeterli olmadığını gösterir.

Soru 4: Milli Mücadele kahramanlarından seni en çok etkileyen hangisi oldu? Açıklar mısın?

Tablo 12. Öğrenci Görüşme Formundaki 4. Sorunun Cevap Dağılımı

\begin{tabular}{llll}
\hline Soru & Cevaplar & Cevap Sayısı & Yüzdelik\% \\
\hline 4. Milli Mücadele kahramanlarından seni en çok etkileyen & Kazım & 9 & 30,0 \\
hangisi oldu? Açklar mısın? & Karabekir & & 36,7 \\
& Şerife Bacı & 11 & 20,0 \\
& M. Kemal & 6 & 6,7 \\
& Atatürk & & 3,3 \\
& Vecihi & 2 & 3,3 \\
\hline
\end{tabular}

Araştırmanın odak noktası olan Sosyal Bilgiler ders kitabında yer alan kahramanlardan sadece ikisinde yoğunlaşma olduğu görülmektedir. Araştırma bulgusuna göre 30 öğrenciden 11'i Şerife Bacı'dan etkilenirken; 9'u Kazım Karabekir'den; 6 öğrenci Mustafa Kemal Atatürk'ten; 2 öğrenci Vecihi'den; 1 Öğrenci Sütçü İmam'dan; 1 öğrenci de Şekerci Ökkeş’ten etkilendiğini söylemiştir. Bu durum öğretmenlerin konuyu işlerken bazı kahramanların üzerinde daha çok durmuş olmasından ya da biyografi temelli anlatımda birden fazla kahramanın kullanılmasının akılda kalıcı olmamasından dolayı olabilir. Öğrencilerin bu soruya verdiği bazı cevaplar şu şekildedir: 
- Ö-12: "Beni en çok Şerife Bacı etkiledi. Çünkü cepheye cephane götürmek için çok fedakârlık yaptı. Soğuk havaya rağmen pes etmedi ve donarak öldü. Bu beni çok etkiledi."

- Ö-15: “Kazım Karabekir'den etkilendim. Çünkü Doğu Cephesi’nde Ermenilerle cesurca savaştı ve ülkemizi düşmandan kurtardı. Çok cesur bir asker olması beni etkiledi."

- Ö-14: "Atatürk beni çok etkiledi. Çünkü eğer o milli mücadeleyi başlatmasaydı yurdumuz düşmanlardan kurtulamazdı."

$\mathrm{Bu}$ çalışmanın araştırmacısı olarak, görüşme sırasında öğrencilerin en çok bu soruyu cevaplandırmada istekli olduğunu gözlemlediğimi söyleyebilirim. Araştırmaya katılan tüm öğrenciler bu soruyu, Milli Mücadele kahramanlarından birini söyleyerek ve gerekçesini de açıklayarak cevaplamışlardır. Öğrencilerle yapılan görüşme sonunda bu sorunun cevabına ilişkin analiz yapıldığında "biyografi temelli öğretimin" faydalı olduğu, kalıcı öğrenme sağladığı görülmektedir.

Soru 5: Ders kitabındaki Milli Mücadele ile ilgili bölümde anlamadığın sözcükler oldu mu?

Ders kitabının kullandığı kelimeler bakımından sınıf seviyesine uygun olup olmadığını değerlendiren bu soruya ilişsin öğrencilerin verdiği cevaplar aşağıdaki gibidir:

Tablo 13: Öğrenci Görüşme Formundaki 5. Sorunun Cevap Dağılımı

\begin{tabular}{llll}
\hline Soru & Cevaplar & Cevap & Yüzdelik\% \\
\hline 5. Ders kitabındaki Milli Mücadele ile ilgili bölümde & Var & 23 & 76,7 \\
anlamadı̆̆ın sözcükler oldu mu? & Yok & 7 & 23,3 \\
\hline
\end{tabular}

Öğrencilerin büyük çoğunluğu (Ö-2, Ö-5, Ö-6, Ö-7, Ö-8, Ö-9, Ö-10, Ö-12, Ö-13, Ö-14, Ö-16, Ö-17, Ö-19, Ö-21, Ö-22, Ö-23, Ö-24, Ö-25, Ö-26, Ö-27, Ö-28, Ö-29, Ö-30): “Ders kitabinda anlamını bilmediğim sözcükler vardır." şeklinde cavap vermişlerdir. "Bu sözcükler nelerdir?" sorusuna verilen cevaplar:

- $\quad$ Taarruz, (Ö-6, Ö-7, Ö-13)

- Muharebe, (Ö-3, Ö-5, Ö-26, Ö-28)

- Karargâh, (Ö-2)

- Mütareke, (Ö-17)

- $\quad$ Ateşkes, (Ö-9, Ö-12, Ö-13)

- Genelge, (Ö-2, Ö-15)

- $\quad$ Mareşal, (Ö-19, Ö-21, Ö-27)

- Antlaşma, (Ö-6, Ö-10) şeklinde olmuştur.

Verilen cevaplardan yola çıkarak ders kitabının kullandığı sözcükler yönüyle sınıf seviyesinin üstünde olduğu görülmektedir.

Soru 6: Milli Mücadele süresince hangi cephelerde savaşılmıştır?

Milli Mücadelenin bir bölümü olan cephelerin öğrenciler tarafından öğrenilip öğrenilmediğini değerlendiren bu soruya ilişkin cevaplar tablodaki gibidir: 
Tablo 14. Öğrenci Görüşme Formundaki 6. Sorunun Cevap Dağılımı

\begin{tabular}{llll}
\hline Soru & Cevaplar & \multicolumn{1}{c}{ Cevap } & Yüzdelik\% \\
& & Sayısı & Doğru \\
\hline \multirow{2}{*}{ 6. Milli mücadele süresince hangi cephelerde savaşılmıştır? } & Yanlış/Boş & 8 & 73,3 \\
& & 226,7 \\
\hline
\end{tabular}

$\mathrm{Bu}$ soruya, görüşme yapılan 30 öğrencinin 22' si doğru cevap vermiştir. Bu sonuca bakarak milli mücadelede savaşılan cephelerin "isimleri” öğrenilmiştir. Cephelerle ilgili detay bilginin sorulmadığı bu soruda öğrencilerin büyük çoğunluğu: (Ö-1, Ö-2, Ö-3, Ö-4, Ö-5, Ö-6, Ö-9, Ö11, Ö-14, Ö-15, Ö-17, Ö-18, Ö-19, Ö-20, Ö-21, Ö-22, Ö-24, Ö-26, Ö-27, Ö-28, Ö-29, Ö-30) "Doğu cephesi, Batı cephesi, Güney cephesi” yanıtını vermiştir.

Soru 7: Milli Mücadeleyi öğrenmende sana en çok faydası olan kaynak nedir? (Ders kitabı, öğretmen, haritalar vb. gibi görseller, izlediğin bir video...)

Öğrencilerin Milli Mücadele dönemini öğrenmesinde, öğretmenden öğrendiklerini dile getirenlerin sayısı, ders kitabını söyleyenlerden çok daha fazla çıkmıştır. Bu soruya ilişkin bulgular aşağıdaki tabloda yer almaktadır.

Tablo 15. Öğrenci Görüşme Formundaki 7. Sorunun Cevap Dağılımı

\begin{tabular}{llll}
\hline Sorular & Cevaplar & $\begin{array}{l}\text { Cevap } \\
\text { Sayısı }\end{array}$ & Yüzdelik\% \\
\hline $\begin{array}{l}\text { 7. Milli mücadeleyi öğrenmende sana en çok faydası olan } \\
\text { kaynak nedir? (Ders kitabı, öğretmen, haritalar vb. gibi } \\
\text { görseller, izlediğin bir video...) }\end{array}$ & Öğretmen & 24 & 80,0 \\
\hline
\end{tabular}

Bu soruya öğrencilerden 24 kişi “öğretmen” cevabını vermiştir. Bu durum bize 4. Sınıf Sosyal Bilgiler dersi Milli Mücadele konusunun öğretiminde, öğretmenin rolünün büyük olduğunu göstermektedir.

Araştırmacı görüşme yaptığı öğrencilere "Neden öğretmen cevabını verdin?” şeklinde soru sorduğunda aldığı cevapların bazıları aşağıdaki gibidir:

- Ö-21: "Çünkü anlamadığım yerler olduğunda öğretmenime sorabiliyorum."

- Ö-15: "Çünkü öğretmenimiz bu konuyu bizim anlayabileceğimiz şekilde anlatabiliyor. Ama kitabı anlamak zor. Kitaptaki cümleler çok karışık ve uzun."

- Ö-8: "Çünkü öğretmenim tahtaya bir şema çizdi. Bu şemada milli mücadele dönemindeki olaylar kısaca anlatılıyordu. Ben o şema ile öğrendim.”

Öğrencilerin verdiği cevaplardan da anlaşılacağı üzere ders kitabının öğrenciler tarafından anlaşılır olmadığı, bu nedenle de konuyu öğretmenden öğrenmeyi tercih ettikleri sonucuna varılıyor. Bu açıdan araştırmaya konu olan Sosyal Bilgiler ders kitabının uygun bir ders materyali olmadığı görülmektedir.

\section{TARTIŞMA ve SONUÇ}

Bu çalışmada ilkokul 4. Sınıf Sosyal Bilgiler ders kitabı "Milli Mücadele" konusu, kronoloji bilgi ve becerisi" ile "değişim ve süreklilik becerisini" kazandırma yeterliliği bakımından incelenmiştir. 2018-2019 eğitim öğretim yılında, MEB'in gönderdiği Sosyal Bilgiler 4. Sınıf 
ders kitabını kronoloji bilgi ve becerisini kazandırması açısında inceleyen bu araştırmada aşağıdaki sonuçlara ulaşılmıştır:

Araştırmaya katılan öğretmenlere, Sosyal Bilgiler dersinin öğretim sürecinde faydalandığ1 kaynak ve materyaller sorulduğunda, sadece iki katılımcının ders kitabından faydalandığ 1 tespit edilmiştir. Öğrencilerle yapılan görüşmede ise "Sosyal Bilgiler dersinde Milli Mücadele dönemini öğrenmede sana en faydalı kaynak ne olmuştur?" sorusuna yanıt olarak 30 öğrencinin 24'ü öğretmen, 6'sı ders kitabı şeklinde cevaplamıştır. Bu durumda hem öğretmen hem de öğrenci katılımcıların Sosyal Bilgiler ders kitabını konu bağlamında yararlanılacak bir materyal olarak görmedikleri söylenebilir. Oysaki dersin işlenişinde en sık başvurulan kaynaklardan olan ders kitapları hem öğretmen hem de öğrenciler açısından yol gösterici ve işlevsel olabilir. Ders kitapları, eğitim programlarında belirlenen amaçlar doğrultusunda; öğretim programlarındaki derslerin içeriği ile ilgili bilgileri öğrencilere sunan, pekiştiren, öğrencilerin öğrenme hızlarına uygun çalışma imkânı sunan, ekonomik bir öğretim materyalidir. Araştırma sonucunda ders kitabının sahip olması gereken bu özellikleri taşımadığı sonucuna ulaşılmıştır.

Araştırmanın bir diğer inceleme alanı olan ders kitaplarının öğrencilerin yaşa bağlı gelişimleri esasına göre düzenlenen sınıf seviyesine uygun olmadığ 1 yine hem öğretmen hem de öğrenci görüşleriyle teyit edilmiştir. Özellikle milli mücadeleyi konu alan bölümde geçen sözcükler, detaylı sunulan "cepheler" konusu, öğrencilerin seviyesinin üstünde değerlendirilmiştir. Ayrıca konu bağlamında pek çok anlamını bilmedikleri sözcüklerin yer alması, çocukların ders kitabını kullanımını zorlaştırmıştır. Zira kitaptaki konu bağlamında öğrencilerin anlamını bilmedikleri sözcüklerin neler olduğu sorulduğunda hem öğretmenler hem de öğrenciler hemen hemen aynı sözcükleri dile getirmişlerdir.

Öğrencilerin zaman algısının gelişmesinde ve tarihsel zamanı doğru algılayabilmesinde kronoloji bilgi ve becerisinin önemi büyüktür. Öğrencinin zihinsel gelişimine paralel olarak hazırlanan, birbiri ile ilişki kurularak sunulan, oluş sırası sebep sonuç bağlamında işlenen bir tarih eğitimi programı bu amaca hizmet edebilir. Ders araç gereçleri kategorisinde en çok başvurulan kaynaklardan olan ders kitaplarının da tarihle ilgili konuları sunarken, öğrencinin seviyesine, hazır-bulunuşluk düzeyine, kronoloji bilgi ve becerisinin doğru işlenmesine dikkat edilerek hazırlanmasında fayda vardır.

Araştırmanın kronoloji bilgi ve becerisine ilişkin bulgularında ise ders kitabının bu becerileri desteklemediği görülmüştür. Görüşme formunda öğrencilere sorulan kronolojik sıralama sorusu 13 öğrenci tarafından doğru cevaplanırken; 17 öğrenci bu soruyu yanlış yanıtlamıştır. Öğretmenler de genel olarak ders kitabının ilgili konuyu fazla detaylı verdiğinden, kronolojik sıralama şeklinde öğrenmeye firsat tanımadığını ifade etmişlerdir. Ayrıca öğretmenler, kitapta Milli Mücadele dönemi içinde yaşanan olayların sıralı bir anlatımla sunulmadığını da dile getirmişlerdir. Madem ki 2018 yılında güncellenen Sosyal Bilgiler dersi öğretim programında yer alan 26 temel beceriden biri "değişim ve sürekliliği algılama becerisi" bir diğeri ise "zaman ve kronolojiyi algılama becerisi" şeklinde belirtilmiştir (Sosyal Bilgiler Dersi Öğretim Programı, 2018). O zaman öğretimin önemli materyali olarak Sosyal Bilgiler ders kitabının da programda belirtilen becerilerin kazandırılmasında yardımcı olacak şekilde hazırlanması beklenir.

Araştırmanın biyografi temelli öğretime ilişkin bulgularına bakıldığında öğretmen ve öğrenci görüşmelerinden elde edilen sonuçların benzerlik göstermediği görülmüştür. Öğretmenler, sosyal bilgiler dersini biyografi temelli işlemek faydalı bulmazken; öğrencilerinse bunu ilginç 
ve akılda kalıcı bulduğu görülmüş̧ür. Görüşme formunda bu bulguya ilişkin yöneltilen soruya katılımcı öğrencilerin tümü bir kahramanı anlatarak ya da onun hayatından örnek vererek cevap vermiştir. $\mathrm{Bu}$ sonuca bakarak biyografi temelli öğretimin öğrencilerin anlamlı ve kalıcı öğrenmesinde etkili olduğunu söyleyebiliriz. Bu durum diğer benzer araştırmalarda da ifade edilmiştir. Örneğin, Oruç ve Erdem'in (2010) çalışmasında Sosyal Bilgiler dersinde biyografi kullanımının öğrencilerin derse ilişkin tutumları üzerinde olumlu etkisi olduğu ortaya konmuştur. Fertig (2008) ise ortaokul ve daha yüksek eğitim basamaklarında tarih konularının öğretiminde biyografilerden yararlanmanın öğrencilerin bilgiyi anlamlı biçimde yapılandırmalarına katkı sağladığını belirtmektedir. Bununla beraber Şimşek ve Çakmakçı'nın (2019) çalışmasında ise 2018 tarihli Sosyal Bilgiler 4 ders kitabının, çocukların ilgisini çeken biyografi ve hikâyelere yer verilmesi yönüyle, öğrenciler açısından ilgi çekici bulunmuştur.

Öğretmen ve öğrencilerle yapılan görüşmelerden elde edilen bütün bu veriler 1şığında kitabın, genel olarak sınıf seviyesinin üzerinde olduğu; kronoloji bilgi ve becerisini kazandırmada yetersiz olduğu; ders materyali olması bakımından öğrenci üzerinde etkili olmadığı sonuçlarına ulaşılmıştır. Bunun yanı sıra 4. Sınıf sosyal bilgiler ders kitabında milli mücadele döneminin "biyografi temelli" olarak ele alınması öğretmenler tarafından faydalı ve gerekli bulunmazken; öğrenciler tarafından faydalı ve etkili bulunduğu görülmüştür.

\section{KAYNAKÇA}

Blyth, J. (1996). History in primary school. Open University.

Dawson, I. (2004). Time for chronology? Ideas for developing chronological understanding. Teaching History, $117,14-24$.

De Groot-Reuvekamp, M., Ros, A., Van Boxtel, C. \& Oort, F. (2017). Primary school pupils' performances in understanding historical time. Education 3-13: International Journal of Primary, Elementary and Early Years Education, 45(2), 227-242.

DeMarrais, K. (2004). Qualitative interview studies: Learning through experience. K. deMarrais, \& S. D. Lapan (Ed.), Foundations for research içinde (s. 51-68). Lawrrence Erlbaum.

Demircioğlu, i. H. (2005). Sekizinci sınıf öğrencilerinin tarih öğretiminde kullanılan zaman ve kronolojiyle ilgili bazı kavramları anlama düzeyi. Eğitim Araştırmaları Dergisi, 19, 155- 163.

Er, H. (2005). Sosyal bilgiler dersinde biyografi ögretimi: “Atatürk'ün hayatı” metninin analizi ve yeni bir tasarım [Yayınlanmamış yüksek lisans tezi]. Gazi Üniversitesi Eğitim Bilimleri Enstitüsü, Ankara, Türkiye.

Er, H. (2010). Sosyal bilgiler eğitimi kapsamında ilköğretim öğrencilerinin "biyografi”" kullanımına ilişskin görüssleri [Yayımlanmamış doktora tezi]. Gazi Üniversitesi Eğitim Bilimleri Enstitüsü, Ankara, Türkiye.

Er, H. \& Şahin, M. (2012). Sosyal bilgiler dersinde “biyografi” kullanımına ilişkin öğrenci görüşleri. Türk Eğitim Bilimleri Dergisi, 10(1), 75-96.

Erciyeş, G. (2007). Öğretim yöntem ve teknikleri. Ş. Tan (Ed.), Öğretim ilke ve yöntemleri içinde (s. 167-253). Pegem Yayıncılık.

Fertig, G. (2008). Using Biography to help young learners understand the causes of historical change and continuity. Social Studies, 99(4), 147-154.

Hallam, R. N. (1967). Logical thinking in history. Educational Review, 19(3), 45-56.

Hodkinson, Alan J. (2004). Does the English curriculum for history and its schemes of work effectively promote primary- aged children's assimilation of the concept of historical time? Some observations based on current research. Educational Research, 46(2), 99-117.

Hoodless, P. (2008). Teaching history in primary school. Learning Matters.

Jahoda, G. (1963). Children's concepts of time and history. Educational Review, 15, 87-105. 

ve Öğrenci Görüşleri ile Incelenmesi

Kaymakc1, S. (24-26 Mayıs 2012). İlköğretim 4. ve 5. sinıf sosyal bilgiler ders kitaplarında edebî ürünlerin kullanımına bir bakış [Bildiri sunumu]. 11. Ulusal Sınıf Öğretmenliği Sempozyumu, Rize, Türkiye.

Kaymakçı, S. \& Er, H. (2013). Sosyal bilgiler öğretim programı ve ders kitaplarında biyografinin kullanımı. Mehmet Akif Ersoy Üniversitesi Ĕ̈itim Fakültesi Dergisi, 13(25), 198-224.

Levstık, L. S. C. \& Barton, K. (1997). Doing history. Lawrence Erlbaum Associates Publishers.

Barton K. C. \& Levstik, L. S. (Summer, 1996). Back when god was around and everything: Elementary children's understanding of historical time. American Educational Research Journal, 33(2), 419-454.

Ros, M., A., \& Van Boxtel, C. (2018). Improving elementary school students' understanding of historical time: effects of teaching with "timewise". Theory and Research in Social Education, 46(1), 35-67.

Van Boxtel, M., Ros, A. C.,, \& Harnett, P. (2014). The understanding of historical time in the primary history curriculum in England and the Netherlands. Journal of Curriculum Studies, 46(4), 487-514.

Millî Eğitim Bakanlığı (2018). Ilköğretim 4 sosyal bilgiler ders kitabı. Tuna Yay.

Millı̂ Eğitim Bakanlığı (MEB) (2018). Sosyal bilgiler dersi öğretim programı, taslak (İlkokul ve ortaokul 4, 5, 6 ve 7. sinuflar), MEB Yayınevi.

Oruç, Ş. ve Erdem, R. (2010). Sosyal bilgiler öğretiminde biyografi kullanımının öğrencilerin sosyal bilgiler dersine ilişkin tutumlarına etkisi. Selçuk Üniversitesi Ahmet Keleşoğlu Eğitim Fakültesi Dergisi, 30, 215229.

Safran, M. ve Şimşek, A. (2006). İlköğretim öğrencilerinde tarihsel zaman kavramının gelişimi. Elementary Education Online, 5(2), 87-109.

Solé, G. (2019). 'Children's understanding of time: A study in a primary history classroom'. History Education Research Journal, 16(1), 158-73.

Şimşek, A. (2006). Illköğretim öğrencilerinde tarihsel zaman kavramının gelişimi ve öğretimi [Yayımlanmamış doktora tezi]. Gazi Üniversitesi Eğitim Bilimleri Enstitüsü, Ankara, Türkiye.

Şimşek, A., \& Çakmakçı, E. (Güz 2019). Cumhuriyet Dönemi ilkokul tarih ders kitaplarında Millî Mücadele. Cumhuriyet Tarihi Araştırmaları Dergisi, 30, 189-227.

Şimşek, A., (2007). İlköğretim 5. sınıf öğrencilerinin kronolojik algılarının geliştirilmesine yönelik yarı deneysel bir çalışma. Kuramdan Uygulamaya Ĕgitim Bilimleri, 7(1), 589-615.

Şimşek, N. (2014). Sosyal bilgilerde ölçme ve değerlendirme. M. Safran (Ed.), Sosyal bilgiler öğretimi içinde (s. 613-666). Pegem A Yayıncilik.

Taş, H., \& Kıroğlu, K. (2018). 2017 İlkokul Sosyal Bilgiler Dersi Öğretim Programı'nın öğretmen görüşlerine göre değerlendirilmesi. Elementary Education Online, 17(2), 697-716.

TDK (Türk Dil Kurumu). (t.y). Büyük Türkçe sözlük: güncel Türkçe sözlük. 16.12.2020 tarihinde, https://sozluk.gov.tr/ adresinden erişilmiştir.

Yıldırım, A. Şimşek, H. (2008). Sosyal bilimlerde nitel araştırma yöntemleri. Pegem A Yayıncılık. 


\title{
EXTENDED ABSTRACT
}

\author{
Investigation of the "National Struggle" Subject in the 4th grade Social Studies Book in \\ Term of Teaching Chronology Knowledge and Skills with Teacher and Students Opinions
}

\section{Introduction}

The main purpose of Social Studies course programe is to prepare students for social life. For getting this purpose, curriculums are prepared to provide a variety of knowledge and skills. The Social Studies course programe which prepared in 2018 was also prepared within this framework; it is designed around some knowledge and skills. While preparing knowledhe and skills, attention should be paid to qualifications such as being appropriate for the level of students and responding to the needs of the age. One of these knowledge and skills is the chronology knowledge and skill that constitutes the historical time. The chronology knowledge and skill that is the subject our study is one of the skills included in the curriculum starting from the 4th grade. In the 2018 Social Studies national curriculum, especially in the theme of "Culture and Heritage", it was stated that chronology knowledge and skills should be processed with a biography-based method. One of the most important resources and materials used in the presentation of the determined programe to the students is the textbooks. Fort his reason textbooks should be prepared in parallel with the determined national programes. In this study, how the theme of "Culture and Heritage", in which chronology knowledge and skills are presented as an outcome, is handled in the determined Social Studies textbook examined.

\section{Method}

In this study, the data were obtained by interview method which is one of the qualitative research tools. The study group of the research consists of 10 classroom teachers working a public school and 30 fourth grade students studying at the same school. Students from six diffrent classes, it has been determined to have five students randomly selected from each class. While the structured interview was made by students, semi-structured interview was made by teachers. The data obtained from the interview forms were examined one by one.

\section{Findings, Result and Discussion}

We can summarize the result of interviews with teachers as fallows: The textbook subject to the research is very intense in terms of content and above the students' level, there is no chronogical order in the section where the "national struggle" process is discussed, events are given out of order, biograpy-based method is not useful, many words used in the book were not understood by students, results were obtained. According to the results of interviews with students were cocluded that; the students could not order the "national struggle" period chronogically, the textbook is too dense and incomprehensible, they learned the subject from their teacher, not the textbook. Unlike the interviews with the teachers, it was determined that the students found the biography-based learning method is useful and meaningful. Becouse all of the student participating in the study stated the name of at least one of the heroes of the "national struggle" and stated why they were affected by them. Based on this result although teachers think opposite, it can be said that biography-based learning method is contributes to students' permanent and meaningful learning. 

ve Öğrenci Görüşleri ile İncelenmesi

As a result, it can be said that the textbook is not sufficient to give chronology knowledge and skills. Howover it can be said that biography-based learning is an effective method for giving chronology knowledge and skills.

\section{(c) (7)}

"International Journal of New Approaches in Social Studies - IJONASS" is licensed under a Creative Commons Attribution-NonCommercial-ShareAlike 4.0 International License. 